\title{
Analysis Results of Yarrow Medicinal Plant Used as Gastroprotective and Its Use in Health
}

\author{
Hayriye Alp \\ Necmettin Erbakan University, GETAT CENTER, Konya, Turkey.
}

Corresponding Author: Hayriye Alp, Necmettin Erbakan University, GETAT CENTER, Konya, Turkey.

Received date: July 19, 2021; Accepted date: Augusł 25, 2021; Published date: September 30, 2021

Citation: Hayriye Alp (2021) Analysis Results of Yarrow Medicinal Plant Used as Gastroprotective And İts Use İn Health. J. Gastroenterology Pancreatology and Hepatobilary Disorders. 5(6) DOI: 10.31579/2641-5194/040

Copyright: () 2021, Hayriye Alp, This is an open access article distributed under the Creative Commons Attribution License, which permits unrestricted use, distribution, and reproduction in any medium, provided the original work is properly cited.

\begin{abstract}
Introduction: Herbal treatments are a sub-branch of traditional and complementary medicine. People generally use it to strengthen health. It is mostly used with the advice of radio-television, internet and friends. Among the side effects, the most frequent allergic reactions can be seen. tandardized products should be used.It is reported that $80 \%$ of the essential oils of mercury (Achillea herba L.) must be monoterpene. Sesquiterpene group is guaianolite, germacranolite, edesmanolite and has anti-inflammatory, anti-edematous, antimicrobial effect. As flavonoid routine, it contains apigenin. Quinine has effects that increase secretion and appetite. It is spasmolytic due to azulene and flavonoids. It is used in gastric mucosa irritations. It is defined as a gastroprotective drug. Azulene and camazulene give wound healing properties to essential oil. The symptoms of inflammation are relieving.
\end{abstract}

Method: Plants (Achillea herba L.) Grown in July Organic Farm in Konya region were used. Analyzes were conducted in the laboratory of the Western Mediterranean Antalya Regional Directorate of Agriculture and Forestry. Total volatile oil content flavonoid amount was determined in the analysis. The amount of essential oil of lavender plant grown in Konya region was measured by hydrodistillation method. Essential oil components were measured by GC-MS / FID method.

Result: In this study, we aimed to present phytochemical analysis of mercury (Achillea herba L.)) Plant grown in Konya region. Total essential oil amount was found to be $0.62 \%$. Piperitone takes the first place with $31.25 \%$ and $\mathrm{p}$-mentha $-1,5$ dien-8-ol with $14.49 \%$ and $\alpha$-pinene with $10.61 \%$. When the content analysis of European countries is examined in the literature studies, it is seen that the amount of Kamuzulen and monoterpene in the plants grown in Estonia region is higher than other European countries (Hungary, Greece, Moldova, Lithuania, and Germany). Millefolii herba is recommended as gastroprotective drug. It is also used after prostate adenectomy because of its antiinflammatory properties.

Keywords; achillea herba L.; konya region; volatile component

\section{Introduction}

Medicinal and aromatic plants have become very popular recently. It is widely used in health promotion $[3,26]$. In the 2000 s, it created an economy of \$ 158 million in the United States. In Brazil, it is seen that this amount reached 160 million dollars in 2007 [8]. These figures tend to increase steadily in the following years [23]. Many people access these products with the advice of social media, internet, and friends without consulting a doctor. Therefore, misuse, side effects, drug interactions, contamination and toxicity can be seen. It is very important that such widely used medicinal and aromatic plants are used in health with the advice of a doctor and that the right products are in the appropriate standardization. Soner et al. It was determined that the most used green tea in the study of. In the same study, $27.2 \%$ of the population stated that they preferred herbal treatments because they had health enhancement, $25.4 \%$ were less harmful, and $17 \%$ had less side effects [27].
Konya is located in the inner Anatolian region as the province with the largest surface area of our country. It has a population of 2,038,555 according to the records of 2011 (tu1k, 2013). It brings. Turkey's Flora "Flora of Turkey and The East Aegean Islands", according to Turkey belonging to 174 families in 1251 genera and more than 12,000 species and taxa (sub-species and varieties) and has a very rich flora $[13,14$, and $18]$.

Plants convert the nutrients they receive from soil, water and sun to primary and secondary metabolites in their bodies and convert many essential oils, tannins, alkaloids to health. When these substances are taken into the body, they strengthen the immune system, accelerate healing, and support tissue and organ functions [15, 21].

Achillea millefolium (yarrow), also known as quince in the community, belongs to the family of chamomile and is a perennial herbaceous variety, 
a very old medicinal plant group. The length of the plant is around 30-90 $\mathrm{cm}$ and it is often covered with hairy structures. It has a special smell. It has flowers forming a white cap and consists of tongue-like tongue flowers. The seeds are small and hard and round in shape. These seeds do not have hairs called papules. It is used among people with indigestion and cold. Dried flowers of the plant are preferred for medical use. In the composition of yarrow, which has an uncomfortable odor and taste with bitter taste, volatile oils, sesqueterpenes, flavonoids and tannins are present. The composition and analysis of the blue colored volatile oil can be affected by the variety of the plant and the harvest time, the region where it grows. In the herba part of the plant, approximately $0.2-0.4 \%$ volatile oil can be found. Volatile oil can contain azulene, limonene, cineol, borneol, pinenes, sesquiterpenes.

Achillea herba $L$. active ingredients, Achillein substance is homeostatic. It also contains salicylic acid and coumarin. The essential oil rate is $0.2-$ $1 \%$. There is about $0.2-0.4 \%$ volatile oil in herba part. It is reported that the rate of volatile oil in the European Pharmacopoeia should be at least $0.2 \%$ and contain Proazulen (Matrix). Although Kamazulen is not found as essential oil in the plant, it is formed during water vapor distillation of Proazulen precursor substance, a colorless compound. Kamazulen gives the essential oil of the plant a dark blue color. It is reported that $80 \%$ of the essential oil of Achillea herba L. must be monoterpene. Among the main components are 6 different chemotypes; there are components 1,8cineol and constant, 1,8-cineol, camphor, and borneol, Sabinen, $\beta$-pinen, 1,8-cineol and artemisiaketon, Camphor and 1,8-cineol linalool, Askraridol [31]. Other components include karyophylline and $\alpha$ bisabolol. Sesquiterpene group is guaianolite, germaranolite, odesmanolite and they show anti-inflammatory, antiedematous and antimicrobial effects.

Use of Yarrow (Achillea herba L.) plant has secretion and appetite increasing effects due to quinine. It is spasmolytic effective due to azulene and flavonoids. It is used in gastric mucosa irritations. It is described as a gastroprotective drug. Azulene and kamazulen give the essential oil a wound-healing property. Inflammation has relieving symptoms. Due to its sesquiterpene structure, it regulates bile flow with its choleretic feature. It shows sympathomimetic effect due to painful substances, improves blood circulation. Because of this feature, it is also used in the treatment of hemorrhoids. Artemisia vulgaris (common wormwood), Achillea millefolium (yarrow perch) is also used in the regulation of menstrual blood $[11,21]$. It is protective against hepatotoxic effects due to its glycosylated flavonoids. It can be used hepatoprotectively in chronic inflammatory liver diseases [31]. Plants used in phytotherapy; botanically appointed, microbiological and chemical controlled, amount of active substance certain, standardized packed and packaged in hygienic conditions must be presented to the patient. United States and various organizations in Europe, toxic medical that can have effects and is very popular they try to set certain standards for plants [4].

\section{Dosage}

Achillea herba L. average is $4.5 \mathrm{~g} /$ day. It can be used as pharmaceutical infusion tea, capsule, liquid, sitting baths. It should be noted that in use it may affect the absorption of iron. Those allergic to the Astraceae family may experience allergic reactions like dermatitis.

\section{Medicinal and Aromatic Plants in Turkey}

Among the plants cultivated in our country, cumin, anise, thyme, mint, red pepper, fennel, poppy, fenugreek, nigella and mustard can be counted [15]. According to the five years of data covering the years 2003-2007 in Turkey, it is made in the field of organic production average 147589 ha of production area of medicinal plants in this area 1.977 ha. The share of medicinal plants in the total area is $1.3 \%$ [15].
Herbalists (herbalists) in the treatment, only the active substance is isolated and conventional therapy aimed at giving on the contrary, within the totality of the maximum effect appeared, all the components of the plant are positive. They argue that they have a share in the impact. According to them, the use of unpurified plant, neutralizing the substances that make up the plant reduces the possibility of side effects due to [24].

In this study, we tried to reveal the analysis of whether the yarrow (Achillea herba L.) plant grown in an organic farm in Konya Region contains enough correct compounds and its use in health.

\section{Method}

Plants Achillea herba L. Dried 20 grams of the plant grown by expert pharmacist in July Organic Farm in Konya region were used. The study was carried out in the spring season in 2017. The analysis of the plants was carried out in the laboratory of the Western Mediterranean Agricultural Research Institute. For analysis of the plant, gas-mass chromatography (GC-FID, GCMS) scanning, hydrodistillation and essential oil quantity were determined.

\section{Plant source}

The mature Achillea herba L.fruits were harvested from Temmuz Organic Farm at 2017, Konya, Turkey. The fresh peels were separated from the fruits (Muammer Sen, phytotherapist- expert pharmacist Konya, Akyokus-organic farm-Turkey) collected the fruits.

\section{Isolation of the volatile compounds}

\section{Microdistitillaton}

The volatiles were obtained by microdistillation of fresh peels $(600 \mathrm{mg})$ using an Eppendorf Microdistiller with $10 \mathrm{ml}$ distilled water per sample vial. The sample vial was heated to $108^{\circ} \mathrm{C} / \mathrm{min}$ and kept at this temperature for $90 \mathrm{~min}$, the heated the $112^{\circ} \mathrm{C}$ at a rate of $20^{\circ} \mathrm{C} / \mathrm{min}$ and kept at this temperature for $30 \mathrm{~min}$. The sample was subjected to a final post-run for 2 min under the same conditions. The collecting vial, containing a solution of sodium chlorid $(2.5 \mathrm{~g})$ and water $(500 \mu \mathrm{l})$ plus and hexane $(300 \mu \mathrm{l})$ to trap volatile components, was cooled to $-5^{\circ} \mathrm{C}$ during distillation. After the distillation was completed, the organic layer in the collection vial was separeted and analysed by gas chromatography (GC) and chromatography mass spectrometry (GC-MS) systems, simultaneously. The distillation was duplicate.

\section{Essential oil amount}

The amount of essential oil is defined as the amount of substance defined in milliliters per $100 \mathrm{~g}$ of anhydrous plant obtained by distillation under the conditions specified in this standard.

The principle of this method is to distill the aqueous suspension of the sample, collect it in a graduated tube containing a certain volume of xylene used to hold the essential oil in the distilled part, wait for the organic and aqueous phases to separate, read the total volume of the organic phase and calculate the essential oil after extracting the xylene volume [28].

\section{Preparation of sample sample:}

Approximately $20 \mathrm{~g}$ of dried plant material prepared for analysis. Weigh the sample. The weighed sample is placed in the glass clevenger flask. Approximately 10 times $(200 \mathrm{ml})$ of pure water is added to the sample. It is subjected to hydrodistilation for approximately 2 hours. Then, the essential oil that accumulates in the graduated section and creates a phase difference with water is read and the result is recorded in ml. Later, starting from the weighing amount, the amount of essential oil is calculated as a percentage. 


\section{Essential Oil Component Determination}

\section{Gas Chromatography Mass Spectrometry Analysis}

Samples are diluted 1: 100 with hexane for study. Volatile oil compound quantity research of the samples was done by capillary column (HP InnowaxCapillary; $60.0 \mathrm{~m} \times 0.25 \mathrm{~mm} \times 0.25 \mu \mathrm{m}$ ) with GC / GC-MS (Gas chromatography (Agilent 7890A) -mass detector (Agilent 5975C)). In the study, $0.8 \mathrm{ml} / \mathrm{min}$ flow amount was treated with helium as the entraining gas, the samples were injected into the machine with a split amount of 40: 1 in $1 \mu$ l. Injector temperature was kept at $250{ }^{\circ} \mathrm{C}$, column temperature program was arranged as $60^{\circ} \mathrm{C}(10$ minutes $)$, from $60^{\circ} \mathrm{C}$ to $220^{\circ} \mathrm{C}, 4$ ${ }^{\circ} \mathrm{C} /$ minute and $220^{\circ} \mathrm{C}$ (10 minutes). Within the framework of the determined temperature plan, the total working time was 60 minutes. Scanning range $(\mathrm{m} / \mathrm{z})$ 35-450 atomic mass unit and electron bombardment ionization $70 \mathrm{eV}$ were used for mass detector, WILEY and OIL ADAMS broadcast outputs were used for the determination of volatile substances. The percentages of the resulting substances were determined with the FID detector, and the substance determination was determined with the MS detector [24].

\section{Identification of the volatile compounds}

The components of the sample were identified by comparison of their mass spectra with those in the in-house'Baser Library of Essential Oil Constituents' Adams Library, [2], MassFinder Library (Hochmuth 2008), WileyGC/MS Library(Mc Lafferty $\delta$ Stauffer 1989) and confirmed by comparison of their retention indices. Theese indications were accomplished by comparison of retention times with authentic samples or by comparison of their relative retention index (RRI) to series of $n$ alkanes. $\mathrm{N}$-alkanes $\left(\mathrm{C}_{8-21}\right)$ were used as reference points in the calculation of relative indices (RRI) (Curver et al 1985). Relative percentage amounts $(\%)$ of separated compounds were calculated from FID chromatograms.

\section{Results}

The total amount of essential oil was $0.62 \%$. This value is seen in accordance with the European Pharmacopoeia. The table below shows the content analysis of Achillea herba L.) Plant. In the microdistilled Achillea herba L. sample piperitone (31,25\%), p-mentha-1,5dien -8 ol $(14,49 \%)$, neo-intermedeol $(10,91 \%)$ were the main compounds. $\alpha-$ pinene $(10.61 \%)$, trans-verbenol $(9,94 \%)$, cis-chyrysanthenol $(6,38 \%)$, cis-chyrysanthenyl( $3,01 \%)$, pinocaryone $(2,07 \%)$, transpinecarveol $(1,92)$ were the other characteristic compounds of the sample.

\begin{tabular}{|l|l|l|l|}
\hline No & RRI & NAME & Quantity (\%) \\
\hline 1 & 1022 & $\alpha$-PINENE & 10.61 \\
\hline 2 & 1126 & VERBENENE & 1,54 \\
\hline 3 & 1130 & SABINENE & 1,46 \\
\hline 4 & 1290 & CYMENE & 1,32 \\
\hline 5 & CIS-P-MENTH-2-EN-1-OL & 0,71 \\
\hline 6 & 1528 & PINOCARYONE & 2,07 \\
\hline 7 & 1572 & CIS-ABINENE HYDRATE & 0,53 \\
\hline 8 & CIS-CHYRYSANTHENYL & 3,01 \\
\hline 9 & & \\
\hline 10 & 1586 & TRANS-PINOCARVEOL & 1,92 \\
\hline 11 & 1680 & TRANS-VERBENOL & 9,94 \\
\hline 12 & 1758 & P-MENTHA-1,5-DIEN-8-OL & 14,49 \\
\hline 13 & 1774 & PIPERITONE & 31,25 \\
\hline 14 & 1814 & CIS-CHYRYSANTHENOL & 6,38 \\
\hline 15 & 2163 & MYRTENOL & 1,07 \\
\hline 18 & & NEO-INTERMEDEOL & 10,91 \\
\hline
\end{tabular}

Table.1 essential oil quantity analysis of Achillea herba L.)

\section{Discussion}

Previously, studies have been published on the volatile compounds of the Turkish Achillea. Water distilled essential oils from the herbal parts of Achillea phrygia, an endemic species in Turkey, was analyzed by GC/MS. Ninety-two and eighty-eight components were characterized representing $99.2 \%$ and $93.5 \%$ of the total components detected in two oil samples respectively. Cis-Piperitol (11.2\%, 31.2\%), trans-p-menth-2-en-1-ol $(11.0 \%, 14.7 \%)$, cis-p-menth-2-en-1-ol $(7.2 \%, 9.9 \%)$ and 1, 8-cineole $(9.1 \%, 9.9 \%)$ were the major constituents of the oils obtained in $0.7 \%$ yield, respectively, from two plant samples. In addition, in one oil sample, camphor (14.5\%) and linalool (9.9\%) were also major constituents [5].

Aerial parts of Achillea millefolium subsp. Millefolium yielded a new sesquiterpene lactone, achillifolin, together with known sesquiterpene lactones, dihydroparthenolide and dihydroreynosin. Known flavonoids, terpenoids and vanilic acid were also isolated [30].

The present work examined the in vitro antimicrobial and antioxidant activities of the essential oil and methanol extract from Achillea biebersteinii Afan. (Asteraceae). The essential oil exhibited antimicrobial activity against 8 bacteria, 14 fungi and the yeast C. albicans, whereas methanolic extract remained inactive. The antioxidative capacity of the samples was evaluated by using DPPH (2,2-diphenyl-1-picrylhydrazyl) and b-carotene/linoleic acid assays. In both assays, the extract showed better antioxidative capacity than the oil. The extract reduced the stable free radical DPPH with lower IC50 value $(89.90 \mu \mathrm{g} / \mathrm{ml})$ than the oil $(8900$ $\mu \mathrm{g} / \mathrm{ml})$. In the b-carotene/linoleic acid assay, the samples were not effectively able to inhibit the linoleic acid oxidation, exhibiting only $22.7 \%$ (the extract) and $16 \%$ (the essential oil) inhibitions at $2 \mathrm{mg} / \mathrm{ml}$, far below than that of BHT $(97.0 \%)$. Total phenolic constituent of the extract was $51 \mu \mathrm{g} / \mathrm{mg}(5.1 \%$, w/w) as gallic acid equivalent. GC-MS analysis of the essential oil resulted in the identification of 64 components representing $92.24 \%$ of the oil. Piperitone, camphor and 1, 8-cineole (eucalyptol) were the main constituents [4].

The in vitro antimicrobial and antioxidant activities of the essential oil and methanol extracts of Achillea millefolium subsp. millefolium Afan. (Asteraceae) were investigated. GC-MS analysis of the essential oil resulted in the identification of 36 compounds constituting $90.8 \%$ of the total oil. Eucalyptol, camphor, $\alpha$-terpineol, $\beta$-pinene, and borneol were the principal components comprising $60.7 \%$ of the oil. The oil strongly reduced the diphenylpicrylhydrazyl radical $\left(\mathrm{IC}_{50}=1.56 \mu \mathrm{g} / \mathrm{ml}\right)$ and 
exhibited hydroxyl radical scavenging effect in the $\mathrm{Fe}^{3+}-\mathrm{EDTA}-$ $\mathrm{H}_{2} \mathrm{O}_{2}$ deoxyribose system $\left(\mathrm{IC}_{50}=2.7 \mu \mathrm{g} / \mathrm{ml}\right.$ ). It also inhibited the nonenzymatic lipid peroxidation of rat liver homogenate $\left(\mathrm{IC}_{50}=13.5 \mu \mathrm{g} / \mathrm{ml}\right)$. The polar phase of the extract showed antioxidant activity. The oil showed antimicrobial activity against Streptococcus pneumoniae, Clostridium perfringens, Candida albicans, Mycobacterium smegmatis, Acinetobacter lwoffii and Candida krusei while waterinsoluble parts of the methanolic extracts exhibited slight or no activity. This study confirms that the essential oil of Achillea millefolium possesses antioxidant and antimicrobial properties in vitro [9].

A. millefolium plant, the highest total antioxidant activity was observed in seed water extract and the lowest total antioxidant activity was observed in flower ethanol extract.

To determined the DPPH radical removal capacity and total phenolic compound amount of the water extracts of the leaves and flowers of Achillea collina plant, which they collected from two different regions. They found that DPPH radical removal capacity was higher in flower extracts than leaves [17].

The extracted Achillea millefolium leaves in water / acetonitrile (70/30) mixture by two different methods and determined the total amount of phenolic compound with DPPH radical removal capacity [2]. DPPH radical cleaning capacity of the extracts obtained from the first type of extraction is $17.82 \%$, the total amount of phenolic compound is $64.5 \mathrm{mg}$ / 100 grams over quercetin; The DPPH radical removal capacity of the extracts obtained from the second type of extraction was $18.31 \%$ and the total amount of phenolic compound was $58 \mathrm{mg} / 100$ grams over quercetin [2].

Yarrow (Achillea herba L.) plant uses include gastric hyperacidity, duodenal ulcer. It can be used with both infusion teas and herbal mixtures. Among the most commonly used plant mixes are Lini semen, Psylli semen, Foenugraeci semen, Althaeae radix /folium, Sinapis albae semen [16].

It is also among the plants used in bladder irrigation after prostate adenoectomy.It was observed in 22 patients that it prevents hemorrhagic and purulent inflammation after adenoectomy, reduces postoperative blood loss and bacteriuria and has no side effects [12].

In the toxicity studies, $20 \mathrm{mg} / \mathrm{kg}$ dose of a mixture including yarrow was used on experimental animals. Both biochemical and histopathologically, it has been shown that it does not cause any toxicity in experimental animals in acute, subacute and chronic periods [25].

Result

Yarrow herb can be used in diseases where inflammation is the first, due to its antioxidant capacity and anti-inflammatory effects, due to its more effective effect instead of synthetic supplements. There are many methods in medicinal and aromatic plant standardization. Correct botanical name, source country or region, harvest time, sensory tests (organoleptic tests of color and odor), macroscopic (can be done with naked eye or authentic sample, such as shape, size, surface character, texture, refraction), microscopic (parenchyma, colenkima, There are fungi, leaf epidermis, calcium oxalate, starch, protein, fat or authentic substances can be compared with samples), chemical (investigation of the presence of secondary metabolites such as alkaloid, cardiac glycosides) and chromatographic (especially Thin Layer Chromatography, TTC) tests [6].

Many medicinal plants (such as chamomile, sage, peppermint, and lemongrass) are used as medicines in the treatment of mild ailments in almost every home without the need for a doctor's advice. It is important to use medicinal plants under doctor's control in order to avoid important side effects (Ozer, 2001).

\section{Acknowledgement}

Thanks to Temmuz Organic Farm and BATAM.

\section{References}

1. Adam M., Dobias, P., Eisner, A. and Ventura, K., (2009) Extraction of antioxidant from plants using ultrasonic methods and their antioxidant capacity. Journal of Separation Science. 32, 288-294.

2. Adams RP.(2007) Identification of Essential Oil Components by Gas Chromatography/Mass Spectrometry. Carol Stream, IL: Allured Publ.Corporation 362 South Schmale Road Carol Stream, Illinois 60188-2787 USAP.53

3. Armstrong K, Schwartz J, Asch D. (1999) Direct sale of Sildenafil (Viagra) to consumers over the Internet. NEJM;341:1389-91.

4. Asımgil A. Medicinal Plants, Timaş Publishing, Istanbul.

5. Baris O. Gulluce M. Sahin F. Ozer H.Kılıc H.Ozkan H. Sokmen M.Ozbek T. (2006) Biological Activities of the Essential Oil and Methanol Extract of Achillea biebersteinii Afan. (Asteraceae) Turk J Biol.30:65-73.

6. Baser KHC. Demirci B. Kaiser R.Duman H. (1998) Composition of the Essential Oil of Achillea phrygia Boiss. et Ball. Journal of essential oil Research. (12);3:327-329.

7. Bayram, E., Kırıcı, S., Tayans, S., Yılmaz, G., Arabac1, O., Kızıl, S., Telci, İ.,(2010) Possibilities to Increase Medicinal and Aromatic Plants Production. Turkey Agricultural Engineering VII. Technical Congress Proceedings Book-I, 437-456, 11- 15.

8. Baytop T.(1999) Treatment with plants in Turkey. Nobel Medical Bookstores. ISBN 975-420-021-1.

9. Bonakdar R. (2002) Herbal cancer cures on the web: noncompliance with the Dietary Supplement Health and Education Act. Fam Med; 24:522-7.

10. Candan F. Unlu M. Tepe B. Daferera D. Polissiou M. Sökmen A. Akpulat H.A. (2003) Antioxidant and antimicrobial activity of the essential oil and methanol extracts of Achillea millefolium subsp. millefolium Afan. (Asteraceae). Journal of Ethnopharmacology. 87(2-3), 215-220.

11. Curvers, J., Rijks, J., Cramers, C., Knauss, K., \& Larson, P. (1985) Temperature pro-grammed retention indexes: calculation from isothermal data. Part 1: Theory. Journal of High Resolution Chromatography, 8, 607-610.

12. Cubukcu B, Meriçli AH, Mat A, Sarıyar G, Sütlüpınar N, Meriçli F: (2002) Phytotherapy. IU Faculty of Pharmacy Publication No: 79, Istanbul.

13. Davidov MI, Goriunov VG, Kubarikov PG. (1995) Phytoperfusion of the bladder after adenomectomy. Urol Nefrol (Mosk). (5): 19-20

14. Davis, P.H. 1965-1985. Flora of Turkey and the East Aegean Islands. Vol. 1-9. Edinburgh: Edinburgh University Press.

15. Davis, P. H., Mill, R.R., Tan, K. (1988) Flora of Turkey and The East Aegean Islands, Vol. 10, Edinburgh University Press. Edinburgh.

16. Faydooglu E. Surucuoglu MS. (2011) Use of Medicinal and Aromatic Plants and Their Economic Significance from Past to Present. Kastamonu Uni. Faculty of Forestry Journal, 11 (1): 52 $-67$.

17. Gawron-Gzella A, Witkowska-Banaszczak E, Dudek M. (2005) Herbs and herbal preparations applied in the treatment of gastric hyperacidity, gastric and duodenal ulcer in cigarette smokers. Przegl Lek. 62 (10): 1185-7.

18. Giorgi, A., Mingozzi, M., Madeo, M., Speranza, G. and Cocucci, M., (2009) Effect of nitrogen starvation on the phenolic metabolism and antioxidant properties of yarrow (Achillea collina Becker ex Rchb.). Food Chemistry. 114, 204-211.

19. Güner, A. Özhatay, N. Ekim, T., Başer, K.H.C. (2000) Flora of Turkey, Volume 11, Edinburgh University Press. Edinburgh. 
20. Hochmuth, D. H. (2008) MassFinder-4, Hamburg, Germany: Hochmuth Scientific

21. Kara H, Aydın S: (2002) Sexual Problems and Solutions. Sen Publications 10, Ankara.

22. Khan, I.A. Smillie, T.J. Craker, L.E., (2005) Quality and Safety Issues Related to Botanicals. Z.E. Gardner (eds.), Acta Horticulturae. 720.

23. McLafferty, F. W., \& Stauffer, D. B. (1989) The Wiley/NBS Registry of Mass Spectral Data, New York: J. Wiley and Sons. Consulting.

24. Mosihuzzaman M, Choudhary MI. (2008) Protocols on safety, efficacy, standardization, and documentation of herbal medicine (IUPAC Technical Report). Pure Appl Chem, 80(10):2195-230.

25. Ozbek H. (2005) Treatment with Plants in Sexual and Gynecological Problems. Van Medical Journal: 12 (2): 170-174.

26. Petlevski R, Hadzija M, Slijepcević M, Juretić D. (2008) Toxicological assessment of P-9801091 plant mixture extract after chronic administration in CBA / HZg mice - a biochemical and histological study. Coll Anthropol. 32 (2): 577-81.

27. Sucher NJ, Carles MC. (2008) Genome-based approaches to the authentication of medicinal plants. Planta Med,74(6):603-23.

28. Soner BC. Sahin AS.Sahin T. (2013) A survey of Turkish hospital patients' use of herbal medicine. European Journal of Integrative Medicine 5, 547-552.

29. Tugrul AY S., O.Cinar., K. Demiray .F, Ayas., (2012) Determination of Quality Characteristics of Dorystoechas hastata Species Collected from Nature in Antalya Flora. Medical and Aromatic Plants Symposium (Proceedings), p: 374.

30. TSE Method (TS 8882).

31. Ulubelen A, Öksüz S, Schuster A. (1990) A sesquiterpene lactone from Achillea millefolium subsp. Millefolium. Phytochemistry.29(12): 3948-3949

32. Zeybek U., Özgüç S. (2019) Amara aromatica medicinal plants and drugs. Modern and Rational Phytotherapy-1. World Medicine Bookstore. 1st edition p. 116-118. ISBN978-605-9615-35-8.
This work is licensed under Creative Commons Attribution 4.0 License

To Submit Your Article Click Here: Submit Manuscript

DOI: $10.31579 / 2641-5194 / 040$
Ready to submit your research? Choose Auctores and benefit from:

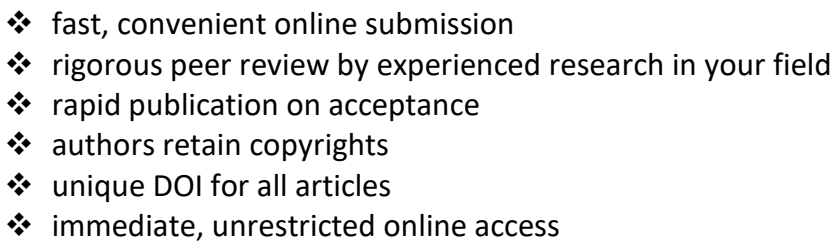

At Auctores, research is always in progress.

Learn more www.auctoresonline.org/journals/gastroenterologypancreatology-and-hepatobilary-disorders 